\title{
Response of white oat genotypes to water stress
}

\author{
Danyela de Cassia da Silva Oliveira, Solange Ferreira da Silveira Silveira, Rafael Valladao Fagundes, \\ Daiana Doring Wolter, Frederico Madabula, Victoria Freitas de Oliveira, Artur Teixeira de Araujo Jr., \\ Clause Fatima Brum Piana, Luciano Carlos da Maia and Antonio Costa de Oliveira*
}

Federal University of Pelotas, Pelotas, RS, Brazil.

*Author for correspondence: acostol@gmail.com

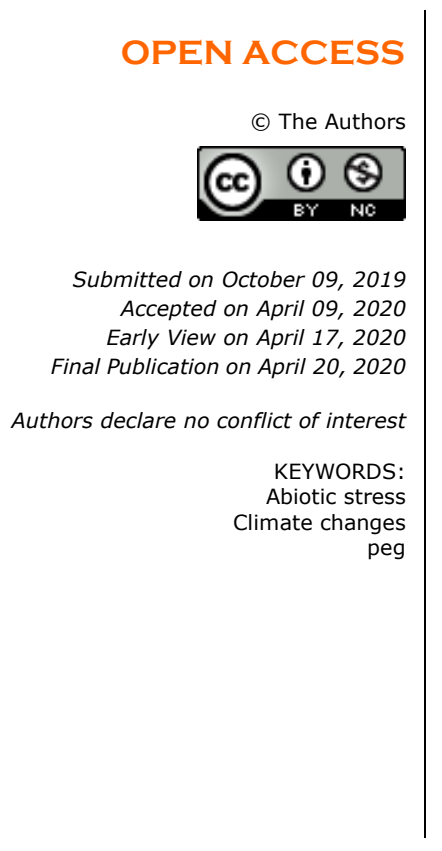

\section{ABSTRACT}

White oat is generally cultivated in areas where there is no problem with water deficit, but due to the expansion of the cultivated areas and climate changes, there is a concern to characterize the genotypes response to water stress. The objectives of this work were to study the variability of responses of white oat cultivars, when subjected to different levels of osmotic potentials and to evaluate the genetic dissimilarity between these, with the use of REMAP markers. To study the variability, two experiments with completely randomized design, conducted in growth chambers were performed, where several oat genotypes in different osmotic potentials were evaluated. To evaluate the dissimilarity among the cultivars, REMAP markers were used. The experiments suggested the characteristics shoot (SL) and root $(R L)$ length as the most affected by the stress. The use of the markers indicated that the similarity among the cultivars varies between 0.80 and 0.58 . The study points out the cultivars URS 21, URS Corona, URS Fapa Slava as being those with the highest level of tolerance to water stress.

\section{Highlighted Conclusions}

1. The $0.8 \mathrm{MPa}$ dose allows the discrimination of cultivars by performance against water stress.

2. The cultivars URS 21, URS Corona and URS Fapa Slava show better performance under water stress.

\section{INTRODUCTION}

White oat (Avena sativa L.) plays a prominent role in world agriculture, due to versatile uses both as grains and forage (Arendt and Zannini 2013). In Brazil, their cultivation occurs mainly in the southern states, where the state of Rio Grande do Sul stands out, being responsible for approximately $70 \%$ of the national production. However, the production of this cereal has been expanding for new areas, reaching the Midwest region (Silveira et al. 2014, CONAB 2019). This cereal is considered as a winter crop, with great importance in the grain production system, besides being used in the integration of livestock farming in Brazilian regions (Silveira et al. 2013).

Among the abiotic factors, drought it is one of the major problems which limit crop growth and yield, affecting overall production (Sultan et al. 2012, Nezhadahmadi et al. 2013). Water stress it is a big problem, because it affects not only the germination rates, but also influence the initial development of the seedlings (Berg and Zeng 2006).

With the expanding areas of oat cultivation, it becomes more important to characterize cultivars in response to water stress. Also, with the advent of climate change, many cultivated areas of this cereal that have not a history of water stress, may suffer changes. There are reports that climate changes represent a serious and worrying risk to Brazils water resources (Marengo 2008).

Breeding for drought tolerance is very important, for enabling crops in regions where water stress is a limiting factor (Girotto et al. 2012). Studies in early stages of development, with morphological characterizations, have been shown as an efficient way for the selection of cultivars adapted to the conditions of water stress, for maintaining correlation with the results found in the field (Chutia and Borah 2012).

In addition to the evaluation of morphologic characters, the use of molecular markers may improve the studies of genetic variability. Among the most commonly used molecular markers in studies of variability are REMAP 
(Retrotransposon Microsatellite Amplified Polymorphism) markers, capable of detecting polymorphisms between retrotransposons and microsatellite regions (Kalendar et al. 1999).

Therefore, the objectives of these work were to study the variability of response of cultivars of white oat, when subjected to different levels of osmotic potentials and to evaluate the genetic dissimilarity between these, with the use of REMAP markers.

\section{MATERIAL AND METHODS}

Experiment 1: Two osmotic potentials. 22 oat cultivars were evaluated: Albasul, Barbarasul, Brisasul, FAEM 4 Carlasul, FAEM 5 Chiarasul, FAEM 06, Fapa Louise, UPFA 20 Teixerinha, Hi-Fi, IAC 7, Leonard, UPFA Temprana, UFRGS 14, UPF 1, UPF 5, UPF13, UPF 15, UPF 16, URS 21, URS Corona, URS Fapa Slava and URS Taura.

Seeds were placed to germinate under normal condition and in the drought stress condition. The artificial condition of water stress was obtained with the preparation of a solution with PEG (polyethylene glycol) to 5\%, which promoted an osmotic pressure of $-0.058 \mathrm{MPa}$, according to Michel and Kaufmann (1973).

Firstly, the seeds were disinfested with the solution of $1 \%$ sodium hypochlorite for 1 minute and washed three times with distilled water. After, they were germinated on germitest paper soaked with 5\% PEG solution for promoting the condition of stress. The control treatment consisted in placing the paper in distilled water (2.5-fold $\mathrm{w} / \mathrm{w}$ ). Later, the rolls with the seeds were maintained in BOD (growth chamber) under temperature of $20{ }^{\circ} \mathrm{C}$, photoperiod of 12/12 (light/dark), for seven days. Each treatment consisted of four repetitions, with 50 seeds each, according to the Rules of Seed Analysis (BRASIL 2009). Experiment was set in a completely randomized design.

The evaluations consisted of \% germination (GER), through counting the seeds germinated after seven days of seeding, shoot length $(\mathrm{SL})$ and root length $(\mathrm{RL})$, measured in centimeters. For each character, ten normal plants per repetition were measured, randomly.

Experiment 2: Four osmotic potentials. There were evaluated 10 cultivars of white oat, selected based on the experiment 1, for presenting differentiated responses to the drought stress, being these: Barbarasul, Brisasul, FAEM 4 Carlasul, FAEM 5 Chiarrasul, FAEM 6 FAEM 7, URS 21, URS Fapa Slava, URS Taura and URS Corona.

In this experiment four different osmotic potentials: $0 ;-0.4 ;-0.8$ and -1.2 Mpa were used, in order to better detail the profile of the most contrasting responses to water deficit. The experiment and the evaluations carried out followed the description for experiment 1.

Experiment 3: Molecular analysis. For the molecular analysis the same cultivars of the experiment 2 were used, with exception of FAEM 7 (Barbarasul, Brisasul, FAEM 4 Carlasul, FAEM 5 Chiarrasul, FAEM 6, URS 21, URS Fapa Slava, URS Taura, URS Corona). The seeds were placed to germinate in (germitest) paper, wet with distilled water. The rolls were put up in growth chamber BOD, photoperiod of 12 hours, maintained to $20{ }^{\circ} \mathrm{C}$, per ten days for obtaining leaf samples. The DNA was extracted through the CTAB extraction method (Saghai-Maroof et al. 1984). After the DNA quantification, an amplification reaction using GoTaq® Green Master Mix (Promega) was performed, according to the protocol indicated by the manufacturer. The amplification program used was a "touchdown" being: one initial denaturation at $94 \stackrel{\circ}{\circ} \mathrm{C}$ for 5 minutes, followed to 35 cycles at $94 \stackrel{\circ}{\circ} \mathrm{C}$ for 1 minute of denaturation. The annealing was obtained with decrease of $1^{\circ} \mathrm{C}$ in the temperature for each cycle (in the break of $62{ }^{\circ} \mathrm{C}$ until $55^{\circ} \mathrm{C}$ ) and the extension occurred at $72{ }^{\circ} \mathrm{C}$ for 1 minute. After the amplification, a final extension at $72 \stackrel{\circ}{\circ}$ for 10 minutes was made. The product of amplification was separated electrophoretically in denaturing $6 \%$ polyacrylamide gel. For the visualization of the amplified fragments after electrophoresis a silver nitrate staining was used (Creste et al. 2001).

The sequences of the REMAP primers used are available in Table 1. The primers were designed based in preserved termination regions (LTRs - Long Terminal Repeats) of the oat (Avena sativa) retrotransposons OARE-1 (AB061327), and Cassandra (AY271960.1). A total of ten primers were designed on dimer microsatellites, Fourteen REMAP combinations were evaluated.

Statistical analysis. A variance analysis was performed for the experiment 1 , to confirm the effect of the treatment factors, allowing further analysis. Then a clustering of means was proceeded using the Scott-Knott $(p \leq 0.05)$ test. Later, the relative performance (Dr) of each character was calculated, to better view the effect of the osmotic concentration in the cultivars, according to the equation:

$$
D r=\frac{\text { Stressed seedlings }}{\text { Stress }- \text { free seedlings }} \times 100
$$

For the data of the experiment 2 first it was obtained the relative performance and with these results proceeded the variance analysis. After the data were subjected to the polynomial regression adjustment, to better represent the individual performance of each genotype in different osmotic potentials. 
Table 1. Primer list used in genetic distance analysis among the eight oat cultivars.

\begin{tabular}{|c|c|}
\hline Description & Primer Sequence \\
\hline \multicolumn{2}{|l|}{ Movable element / ID } \\
\hline Retrotransposon Cassandra / & CTAGCGCATGGCTCAATAGGAT \\
\hline AY271960.1 & GACTAACCCCACAGACCAACAC \\
\hline Ty1-copie retrotransposon OARE1/ & TTCGCTTAGTTTGGGTCTGTCC \\
\hline AB061327 & ACGACTACATCACCCATGTTCC \\
\hline Ty1-copie retrotransposon TAS1 / & TTTACCTTTCGGTGATCCGTGT \\
\hline AJ269530 & AACACCACAGCGTAATGGTTTG \\
\hline \multicolumn{2}{|l|}{ ISSR } \\
\hline $\operatorname{ISSR}(\mathrm{TA})_{25} \mathrm{~A}$ & TATATATATATATATATATATATAA \\
\hline $\operatorname{ISSR}(\mathrm{TA})_{25} \mathrm{C}$ & TATATATATATATATATATATATAC \\
\hline $\operatorname{ISSR}(\mathrm{TA})_{25} \mathrm{~T}$ & TATATATATATATATATATATATAT \\
\hline $\operatorname{ISSR}(\mathrm{TA})_{25} \mathrm{G}$ & TATATATATATATATATATATATAG \\
\hline $\operatorname{ISSR}(\mathrm{CT})_{25} \mathrm{~A}$ & СтСтстстстстстстстстстСТАG \\
\hline $\operatorname{ISSR}(\mathrm{CT})_{23} \mathrm{G}$ & 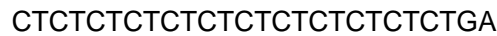 \\
\hline $\operatorname{ISSR}(\mathrm{CT})_{23} \mathrm{C}$ & стстстстстстстстстстстСтGС \\
\hline $\operatorname{ISSR}(\mathrm{GA})_{23} \mathrm{~A}$ & GAGAGAGAGAGAGAGAGAGAGAA \\
\hline $\operatorname{ISSR}(\mathrm{GA})_{23} \mathrm{~T}$ & GAGAGAGAGAGAGAGAGAGAGAT \\
\hline $\operatorname{ISSR}(\mathrm{GA})_{23} \mathrm{C}$ & GAGAGAGAGAGAGAGAGAGAGAT \\
\hline
\end{tabular}

The analysis was performed with the use of SAS (SAS 1999) statistical program and the graphics generated in the SIGMAPlot (SigmaPlot 2000) program.

For the molecular data, obtained in the experiment 3 , scores 0 and 1 were used in the construction of an array of binary data. The values of similarity were calculated adopting the Coefficient of Simple Coincidence ("Simple Matching") (Sokal and Michener 1958). From the distance matrix a dendrogram was built by hierarchical grouping method (UPGMA -Unweighted Pair Group Method with Arithmetic Mean). The adjustment between the distance matrix and the respective dendrogram was estimated through the coefficient of correlation ( $r$ ) (Sokal and Rohlf 1962). These analyses were performed with the aid of NTSYS pc 2.1(Rohlf 2000) computer program.

\section{RESULTS}

Experiment 1. According to the variance analysis (Table 2), the interaction between the factors cultivar and treatment, was significant for all the characters analyzed, indicating that the cultivars studied present different responses to treatment, justifying the analysis of factors by grouping of means.

Table 2. Summary of the analysis of variance with real dates for germination (GER), root length ( $R L)$ and shoot length $(S L)$, in oats genotypes subjected to two condition of hydric stress for seven days in the chamber.

\begin{tabular}{lcccc}
\hline \multirow{2}{*}{ SV } & DF & \multicolumn{2}{c}{ MS } & SL \\
\cline { 3 - 5 } \cline { 4 - 4 } CULTIVARS (C) & 21 & $493.17^{*}$ & $7.53^{*}$ & $6.41^{*}$ \\
TREATMENT (T) & 1 & $24181.64^{*}$ & $1.24^{*}$ & $94.55^{*}$ \\
C X T & 21 & $675.28^{*}$ & $2.95^{*}$ & $3.10^{*}$ \\
ERROR & 132 & 6.59 & 0.12 & 0.07 \\
\hline MEAN & & 83.05 & 4.99 & 6.44 \\
CV (\%) & 3.09 & 6.83 & 4.24 \\
\hline ** significant at $p \leq 0.01$ by the F test; * significant at $p \leq 0.05$ by the F test; GER=germination; RL=root length; SL= \\
shoot length.
\end{tabular}

When comparing the two osmotic conditions, during the germination (Table 3), it is noted that only the cultivars FAEM 6, Hi-Fi and UFRGS14 had the same performance in both conditions. The other cultivars presented higher performance in the control condition, demonstrating to be adversely affected by the reduction of osmotic potential, by the addition of PEG.

When analyzed the germination under the control condition, there were three groups, where 18 of the cultivars in study had similar performance and higher potential than the others. However, in the stress condition there were eight groups formed. The cultivars that better performed were FAEM 6 and URS Corona, both with germination above $90 \%$. The cultivar FAEM 4 Carlasul presented the lowest performance, with only $33.3 \%$ germination in this condition.

When analyzing the relative performance, it was observed that ten cultivars have performed above $80 \%$ of germination and four cultivars (FAEM 4 Carlasul, FAEM 5 Chiarrasul, Leonard and URS 21) presented inferior performance to $50 \%$. It should be noted that these four cultivars when in the control condition were present in the 
group of high performance, not being possible to correlate high performance in germination under normal conditions with the probability of success under water stress.

For the character RL, the cultivars FAEM 4 Carlasul, FAEM 5 Chiarasul, Hi-Fi, IAC 7, UPFA Temprana, UFRGS 14, UPF 5 and URS Taura did not change their performance in the stress condition. In this condition the cultivars Albasul, FAEM 6, Fapa Louise, UPF 15, UPF 13, URS 21 and URS Corona increased the root length, while for the other cultivars there was a reduction of the character.

In the control condition it was observed the formation of seven groups, where the cultivar UPF 16 was the one who presented higher $\mathrm{RL}(8.2 \mathrm{~cm})$, when compared with the other cultivars. On the other hand, the cultivars Albasul, Fapa Louise, UPF 13 and URS Taura presented smaller developments in their root systems.

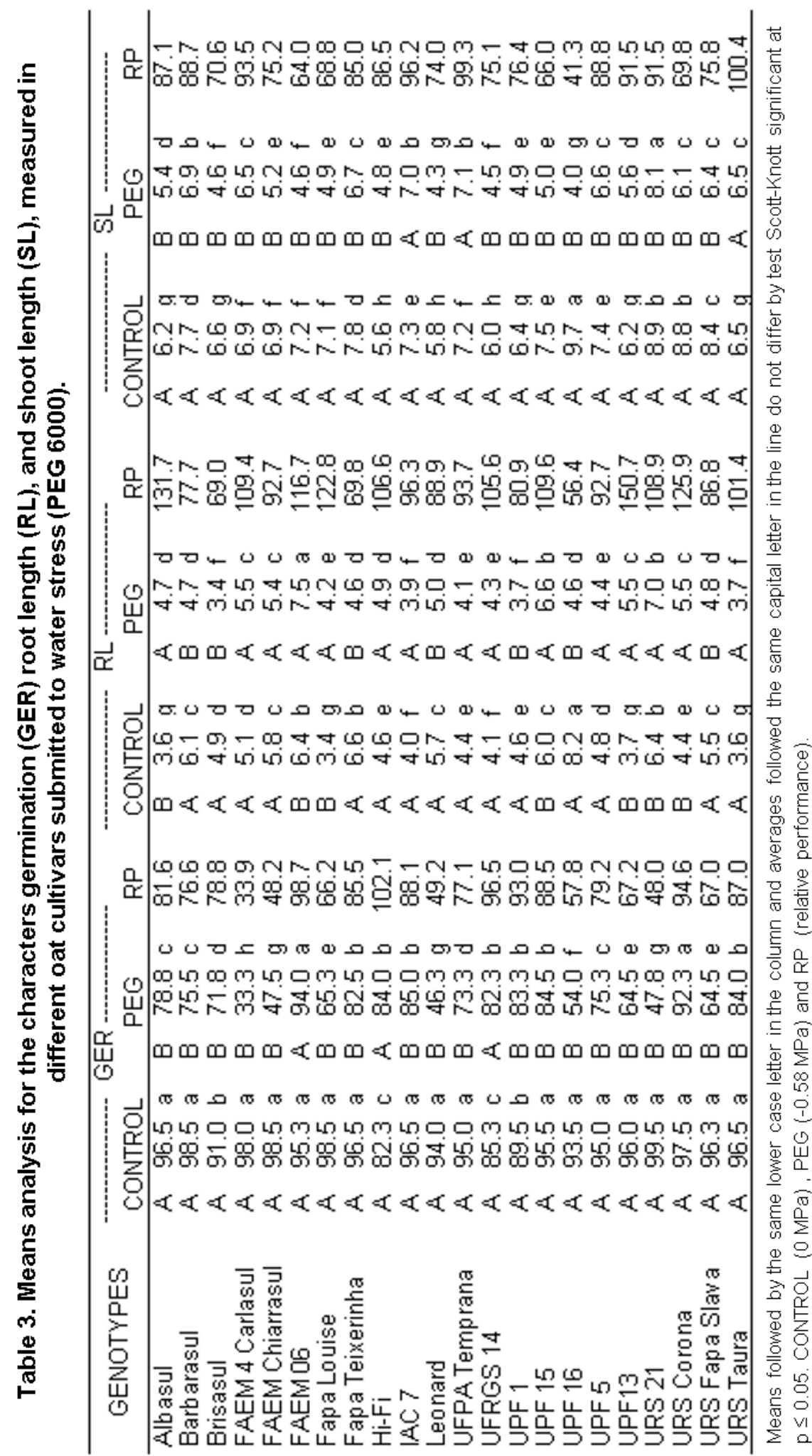


The cultivar FAEM 6 in the water stress condition presented the highest $R L(7.5 \mathrm{~cm})$ differing from the others. The cultivars Brisasul, IAC 7, UPF 1 and URS Taura were the cultivars that had the smaller root systems. Although the cultivar URS Taura has been placed in the lower performance group, it was possible to note that it was part of the cultivars that did not present significant difference between the conditions, suggesting that the water stress proposed did not alter the physiological metabolism.

When analyzing the two conditions through the relative performance, it is possible to observe that many cultivars had their root affected in the treatment condition. Among these, the cultivars Albasul, FAPA Louise, UPF13 and URS Corona stood out, with an increase of more than $20 \%$ in the character. The other cultivars had their root lengths reduced in this condition, with decreases of up to $43.6 \%$ (UPF 16) when compared to the control condition.

For the character SL, it was observed that the cultivars IAC 7 UFPA Temprana and URS Taura had similar performance under both conditions. The other cultivars had their shoot length reduced in the treatment condition.

When analyzing the cultivars in control condition, it was observed the formation of eight different groups indicating the existence of variability among the cultivars under study. The cultivar UPF 16 presented higher SL $(9.7 \mathrm{~cm})$, while the cultivars that present less development of shoot length, were Hi-Fi, Leonard and UFRGS 14.

In the treatment condition there were seven group formation, being the cultivar URS 21 stood out with longer SL and the cultivars Leonard and UPF 16, which presented the shorter length.

When analyzing the cultivars based in the relative performance, it was noted that the cultivar URS Taura maintained the same performance presented in the control condition, while the others suffered reductions in the shoot length. It was noted that the URS Taura did not suffer changes in both characters, RL and SL, suggesting that the cultivar presents some level of resistance of water stress. The cultivar which showed the greatest reduction was the cultivar UPF 16 (58.7\%).

Experiment 2. According to the analysis of variance (Table 4), the interaction between the factors cultivars and osmotic potentials was significant for all the analyzed characters, indicating the cultivars studied present differences in response to stress, justifying the partition of the factors by a regression (Figure 1).

Table 4. Summary of the analysis of variance with relative dates for germination (GER), root length (RL) and shoot length (SL), in oats genotypes subjected to four levels of hydric stress for seven days in the chamber.

\begin{tabular}{|c|c|c|c|c|}
\hline \multirow{2}{*}{ SV } & \multirow{2}{*}{ DF } & \multicolumn{3}{|c|}{ MS } \\
\hline & & GER & $\mathrm{RL}$ & SL \\
\hline CULTIVARS (C) & 9 & $276.4^{\star *}$ & $1001.8^{\star *}$ & $172.9^{* *}$ \\
\hline TREATMENT (T) & 3 & $99241.9^{* *}$ & $79874.2^{* *}$ & $83686.3^{\star *}$ \\
\hline $\mathrm{CXT}$ & 27 & $221.1^{* *}$ & $529.9^{\star *}$ & $113.2^{\star *}$ \\
\hline ERROR & 120 & 55.0 & 74.1 & 12.2 \\
\hline MEAN & - & 46.5 & 49.4 & 35.4 \\
\hline CV (\%) & - & 15.9 & 17.4 & 9.9 \\
\hline
\end{tabular}

In this experiment, it was considered more restrictive doses, in general all the characteristics evaluated were negatively affected (relative performance reduction), with the decrease of osmotic potentials. Also, the dose of -1.2 $\mathrm{MPa}$, was extremely restrictive preventing the germination of all the cultivars and consequently making it impossible the measurement the other characters. At the osmotic potential of $-0.8 \mathrm{Mpa}$, the cultivars Brisasul and FAEM 5 Chiarrasul were so affected that had GER null. The cultivar FAEM 5 Chiarasul already showed susceptibility to water deficit in the experiment 1, however Brisasul had shown more resistant behavior.

For the variable GER, the cultivars with greater performance in the potentials that allowed to discriminate the cultivars (exception the potential of $-1.2 \mathrm{MPa}$ ), were URS Corona URS Fapa Slava and URS 21. The other cultivars in the osmotic potential $-0.8 \mathrm{MPa}$ had performance below $10 \%$, of the performance when compared with the control condition.

For the RL, it was noted that the relative performance was affected in smaller magnitude, since a comparison between the control condition and the first osmotic potential $(-0.4 \mathrm{MPa})$, a reduction of $28 \%$ of relative performance was observed. However, when compared the performance between the second and the third osmotic potentials ($0.4 \mathrm{MPa}$ and $-0.8 \mathrm{MPa}$ ), there was a reduction of relative performance of $73 \%$. The cultivars with higher performance, considering mainly the osmotic potential of $-0.8 \mathrm{MPa}$, which was the most restrictive, were Barbarasul, URS Corona, URS 21 and URS Fapa Slava with relative performance higher than $40 \%$, being that the last two showed higher performance than $50 \%$. 

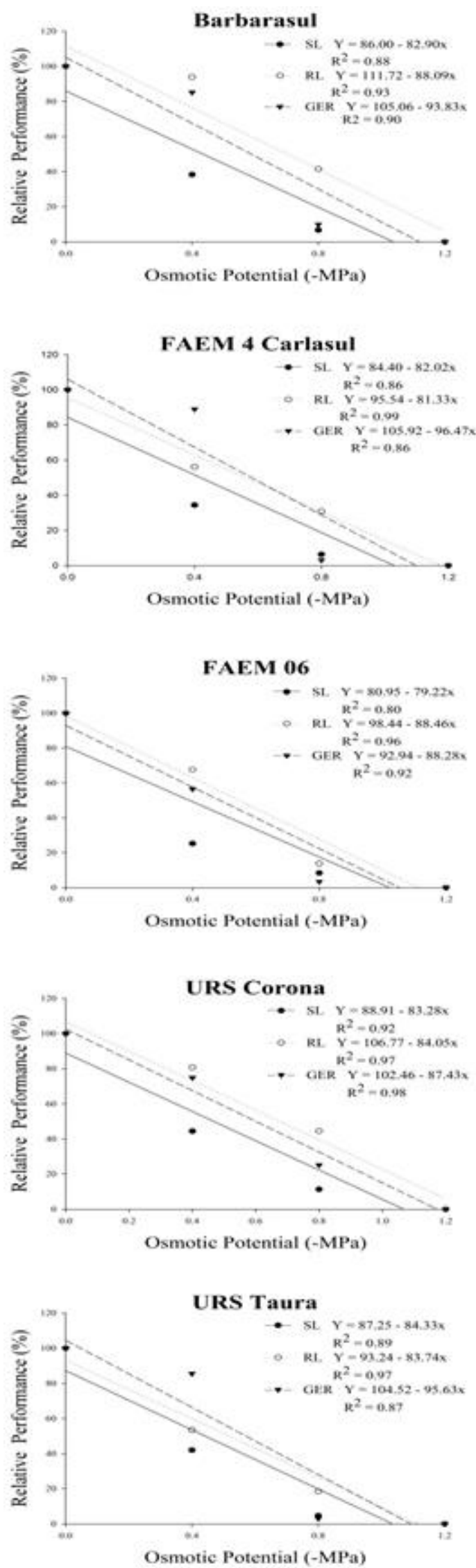

Figure 1. Graphical representation of regression equations adjusted for the performance of oat cultivars for the traits germination (GER), root length (RL) and shoot length (SL) when subjected to water stress by different osmotic potentials.

SL was the most affected variable, because on average, between the control treatment and the osmotic potential of $-0.4 \mathrm{Mpa}$, there was a reduction of $65 \%$ of the relative performance of the cultivars. In the osmotic
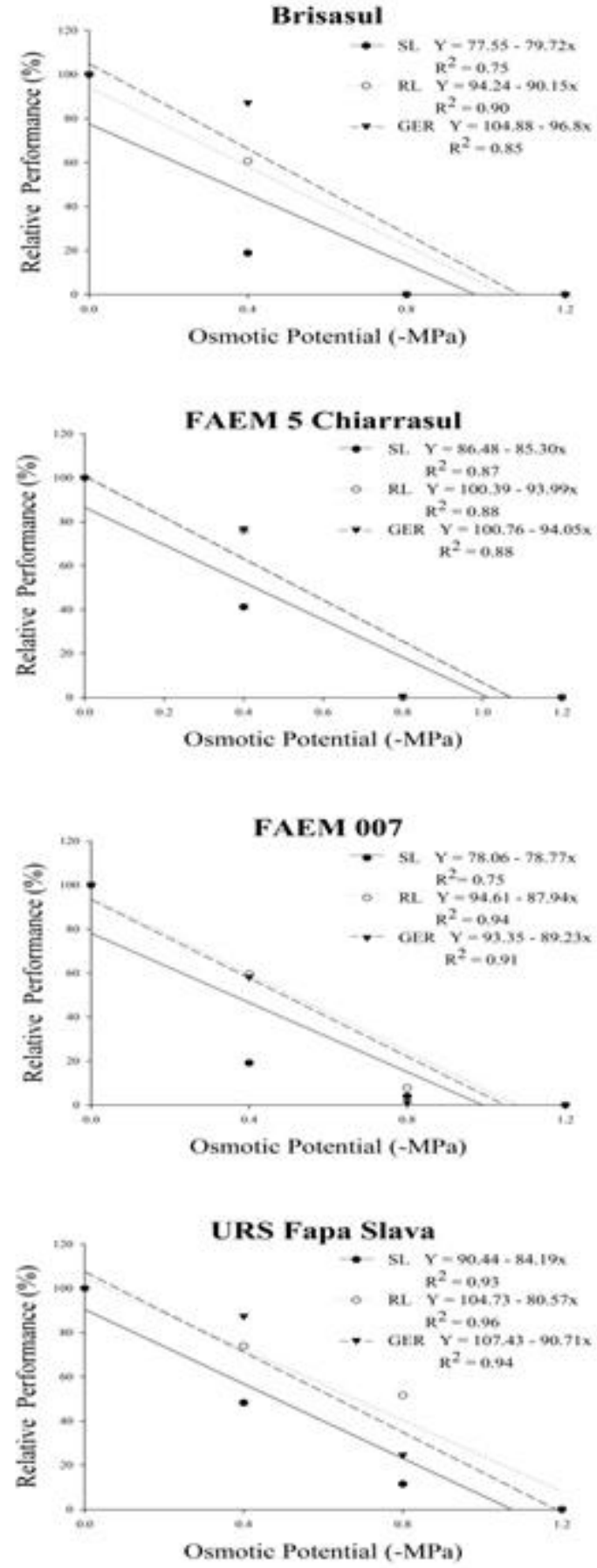

URS 21

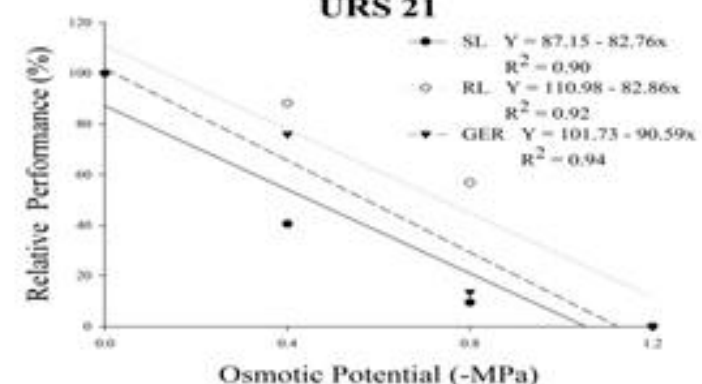


potential of $-0.8 \mathrm{MPa}$, the relative performance reduced further, only the cultivars URS Corona and URS Fapa Slava, presented performances above $10 \%$. The cultivars FAEM 7, URS Taura, presented relative performance under $5 \%$.

Experiment 3: With fourteen combinations evaluated a total of 111 polymorphic fragments were amplified. The dendrogram (Figure 2) generated by the grouping method UPGMA indicated that the maximum and minimum similarity found among the cultivars were equal to 0.80 and 0.58 , respectively.

The cophenetic coefficient was equal to 0.73 , indicating reliability of the dendrogram graph.

As can be seen in Figure 2, the most distant groups of cultivars were G1 (URS 21, URS FAPA Slava and URS Taura) and G2 (Barbarasul, Brisasul and URS Corona), with similarity of 0.58 . It was also observed that the cultivars FAEM 5 Chiarasul and FAEM 6 are very similar between them, about 0.80 of similarity.

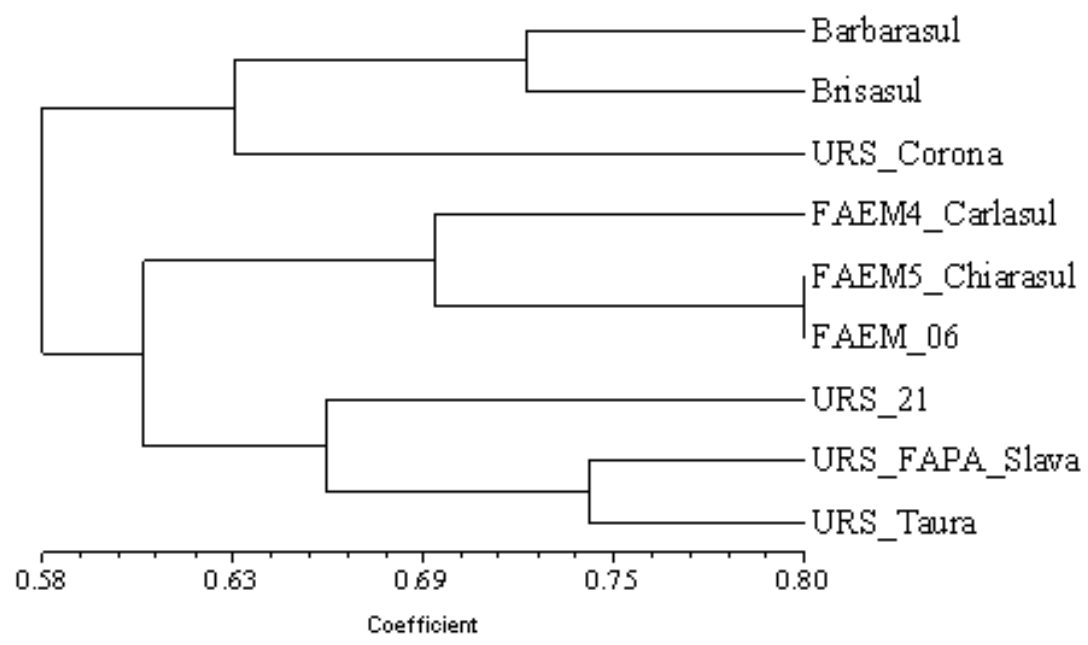

Figure 2. Dendrogram showing nine oat cultivars, obtained by the analysis with REMAP markers, using the simple matching index and UPGMA clustering. Cophenetic correlation coefficient (r) equal to 0.73 .

\section{DISCUSSION}

It is known that plant development is closely linked to cell expansion, responsible for organ development, which is influenced by many factors, including water availability (Taiz and Zeiger 2006, Bashline 2014).

When the plants are subjected to water stress condition, a series of physiological and biochemical processes can be changed, including the ability of plants to acquire water and nutrients, which directly and indirectly affects plant growth, by the reduction of cell expansion, and consequently their final yield (Ashraf et al. 2011). One of the first measurable effects of water stress is the decrease in growth (Taiz and Zeiger 2006, Liberatore et al. 2016).

When the two experiments ( 1 and 2 ) are compared, it is noted that the reduction of osmotic potential even though in smaller intensity reduces germination in the oat seeds. In the experiment 1 , only three cultivars maintained their performances under both conditions. The other cultivars had their germination reduced in the condition of treatment with PEG. The reduction of the germination rate it is related to the reduction of water availability, which inhibits the metabolic reactivation of the cells, responsible for the physiological changes in the initial germination phase (Kerbauy 2004).

The GER reduction in oat seed due to the reduction of osmotic potential was previously reported (Mut and Akay 2010). Similar results have also been found in species such as Triticum aestivum L. (Ahmadi et al. 2012), Triticosecale Witm. (Kaydan and Yagmur 2008) Lens culinaris L. (Muscolo et al. 2014) and in grasses Anthephora pubescens, Heteropogon contortus, and Themeda triandra (Berg and Zeng 2006).

In the experiment 2, where more restrictive doses were tested, the GER was reduced. In the potential of -1.2 $\mathrm{Mpa}$, the restriction was so strong that it inhibited the germination of all cultivars. In the potential of -0.8 , the cultivars Brisasul and FAEM 5 Chiarasul did not germinate, proving to be the most sensitive cultivars of the experiments. Studies with the wheat crop, using the same osmotic potentials used in this experiment (PEG 6000), also demonstrated that as the osmotic potential reduced, the GER was negatively affected (Ahmadi et al. 2012).

When analyzing the experiment 1 , for the $R L$ there is a tendency that the cultivars maintain their developments under both conditions or even increase their root systems in the conditions of low water (0.058 MPa). Previously, Berg and Zeng (2006), observed that the dose of $-0.3 \mathrm{MPa}$ was capable of estimating the root growth of grasses (Anthephora pubescens, Heteropogon contortus), though higher doses have tended to reduce this character. The 
authors suggested that the increase reflects an adaptive response of plants in the search for water. The work with species of the genus Hordeum observed an increase of root development in the condition of water stress (Guoxiong et al. 2002).

Other work aiming to study levels of osmotic potentials, using PEG and three classes of triticale seed sizes, reported that in low concentration $(0.45 \mathrm{MPa})$, small and medium seeds, in general, tend to increase root length, while large seeds tends to keep the same development in the control condition (Kaydan and Yagmur 2008). However, at higher doses $(-0.77,1.03 \mathrm{MPa})$ the root length was reduced and at the dose of $-1.03 \mathrm{MPa}$ there was no seedlings formation from the small seeds. At the highest dose $(-1,44 \mathrm{Mpa})$, none of the seed sizes was able to develop the root system (Kaydan and Yagmur 2008). This trend of reduction of root length was observed in the experiment 2, that used more restrictive doses, where in the potential of $-1.2 \mathrm{Mpa}$, there was no germination for any of the cultivars, preventing the measurement of the variable. In the potential of -0.8 the cultivars Brisasul and FAEM 5 Chiarasul did not germinate and only four cultivars presented a relative performance above $40 \%$.

Studies with white oat, using PEG 6000, as a solute in osmotic conditioning, also demonstrate that with a decrease in osmotic potentials reduction occurred in the RL (Mut and Akay 2010, Mut et al. 2010).

The reduction of shoot length has been considered as one of the main responses of plants to water stress (Kerbauy 2004). In fact, for both the experiments, the cultivars subjected to stress condition had their SL reduced. In the experiment 1 , only three cultivars maintained their performances in both conditions, the others suffered reductions. The reduction of shoot length, when the plants are exposed to water stress, were also observed in a previous study, evaluating the effects of seed size and the osmotic stress, in the germination and in the growth of seedling of different white oat genotypes (Mut and Akay 2010; Mut et al. 2010).

According to Guoxiong et al. (2002) the resistance of water stress is related to the reduction of shoot length in the genus Hordeum.

In the experiment 2, in the condition of $-0.8 \mathrm{Mpa}$, only two cultivars presented relative performance above $10 \%$. Reports with Avena sativa demonstrate that shoot length is extremely affected by the reduction of the osmotic potentials (Mut and Akay 2010, Mut et al. 2010). Also, in triticale this same performance was reported (Kaydan and Yagmur 2008).

With the use of molecular markers (REMAP), it was possible to observe that the maximum and minimum similarity found among the cultivars it was equal to 0.80 and 0.58 , respectively, demonstrating the existence of variability between the genotypes. These molecular markers have also been shown to be efficient in studies of phylogeny and variability in other species as Oryza sativa (Branco et al. 2007) Medicago sativa (Mandoulakani et al. 2012), Triticum aestivum (Nasri et al. 2013) and Zea mays (Kuhn et al. 2014).

Based on REMAP markers, there was no relationship between the grouping generated and the similarity of the performance of the cultivars regarding the stress, not enabling the use of these combinations of markers to study the proposed stress, based on the evaluated characteristics.

The dendrogram indicated that, with exception of the cultivar URS Corona, there is a tendency of the cultivars that group according to the breeding program of origin, which suggests that each program prioritizes certain genotypes with parents that will compose the crossing block. This study of variability is of utmost importance to direct the crossing blocks in breeding programs (Onaga 2013). The cultivars URS 21, URS Corona, URS Fapa Slava had high performance in all the characteristics, and when analyzed with markers, the cultivar URS Corona was genetically distant to the others, suggesting that the crossing between them, can generate a progeny with higher performance of the characters studied due the complementarity of favorable alleles.

In our study condition, the $0.8 \mathrm{MPa}$ dose allows the discrimination of cultivars by performance against water stress. The present study indicates the cultivars URS 21, URS Corona and URS Fapa Slava presented better performance under water stress among commercial cultivars studied. The REMAP markers combination used allows the separation of cultivars studied in different groups, however, there is no relationship with the morphological performance for water stress.

\section{Acknowledgements}

The authors are thankful to FAPERGS, CNPq and CAPES for grants and fellowships.

\section{References}

Ahmadi G et. al. 2012. Study of drought tolerance of bread wheat (Triticum aestivum L.) genotypes in seedling stage. Biharean Biologist 6: 7780.

Arendt EK and Zannini E. 2013. Oats. In: Cereal Grains for the Food and Beverage Industries. Elsevier, 243-283.

Ashraf M et al. 2011. Drought Tolerance. In: Advances in Agronomy. Elsevier Inc. pp.249-296.

Bashline L et. al. 2014. Cell wall, cytoskeleton, and cell expansion in higher plants. Molecular Plant 7: 586-600. 
Berg LV et. al. 2006. Response of South African indigenous grass species to drought stress induced by polyethylene glycol (PEG) 6000 . South African Journal of Botany 72: 284-286.

Branco CJS et al. 2007. IRAP and REMAP assessments of genetic similarity in rice. Journal of Applied Genetics 48: 107-113.

BRASIL. 2009. Ministério da Agricultura, Pecuária e Abastecimento. In: Regras para Análise de Sementes. Brasília, 398p.

Chutia J and Borah SP. 2012. Water Stress Effects on Leaf Growth and Chlorophyll Content but Not the Grain Yield in Traditional Rice (Oryza sativa Linn.) Genotypes of Assam, India II. Protein and Proline Status in Seedlings under PEG Induced Water Stress. American Journal of Plant Sciences 03: 971-980.

CONAB. 2019. Companhia Nacional de Abastecimento: Acompanhamento da safra Brasileira Grãos. Available at:https://www.conab.gov.br/info-agro/safras/graos/boletim-da-safra-de-graos.pdf. (Boletim Grãos Setembro 2019 - Completo) Accessed Oct. 09, 2019.

Creste $\mathrm{S}$ et al. 2001. Detection of single sequence repeat polymorphisms in denaturing polyacrylamide sequencing gels by silver staining. Plant Molecular Biology Reporter 19: 299-306.

Girotto L et. al. 2012. Tolerância à seca de genótipos de trigo utilizando agentes indutores de estresse no processo de seleção. Revista Ceres 59: 192-199.

Guoxiong $\mathrm{C}$ et. al. 2002. Comparative study on morphological and physiological traits related to drought resistance between xeric and mesic Hordeum spontaneum lines in Israel. Barley Genetics Newsletter 32: 22-33.

Kalendar R et. al. 1999. IRAP and REMAP: two new retrotransposon-based DNA fingerprinting techniques. TAG Theoretical and Applied Genetics 98: 704-711.

Kaydan D and Yagmur M. 2008. Germination, seedling growth and relative water content of shoot in different seed sizes of triticale under osmotic stress of water and $\mathrm{NaCl}$. African Journal of Biotechnology 7: 2862-2868.

Kerbauy GB. 2004. Fisiologia Vegetal. Rio de Janeiro: Guanabara Koogan.

Kuhn BC et. al. 2014. Genetic diversity of maize germplasm assessed by retrotransposon-based markers. Electrophoresis 35: 1921-1927.

Liberatore KL et. al. 2016. The role of mitochondria in plant development and stress tolerance. Free radical biology \& medicine 100: $238-256$.

Mandoulakani BA et. al. 2012. Retroelement Insertional Polymorphism and Genetic Diversity in Medicago sativa Populations Revealed by IRAP and REMAP Markers. Plant Molecular Biology Reporter 30: 286-296.

Marengo JA. 2008. Água e mudanças climáticas. Estudos Avançados 22: 83-96.

Michel BE and Kaufmann MR. 1973. The osmotic potential of polyethylene glycol 6000. Plant Physiology 51: 914-6.

Muscolo A et. al. 2014. Effect of PEG-induced drought stress on seed germination of four lentil genotypes. Journal of Plant Interactions 9: 354363.

Mut Z and Akay H. 2010. Effect of seed size and drought stress on germination and seedling growth of naked oat (Avena sativa L.). Bulgarian Journal of Agricultural Science 16: 459-467.

Mut Z, et. al. 2010. Effects of seed size and drought stress on germination and seedling growth of some oat genotypes (Avena sativa L.). African Journal of Agricultural Research 5: 1101-1107.

Nasri S et al. 2013. Retrotransposon Insertional Polymorphism in Iranian Bread Wheat Cultivars and Breeding Lines Revealed by IRAP and REMAP Markers. Biochemical Genetics 51: 927-943.

Nezhadahmadi A et al. 2013. Drought Tolerance in Wheat. The Scientific World Journal 2013: 1-12.

Onaga G, et. al. 2013. Morphological and genetic diversity analysis of rice accessions (Oryza sativa L.) differing in iron toxicity tolerance. Journal of Crop Science and Biotechnology 16: 53-62.

Rohlf FJ. 2000. NTSYS-pc: Numerical taxonomy and multivariate analysis system, version 2.1. Exeter Software. New York.

Saghai-Maroof M A et. al. 1984. Ribosomal DNA spacer-length polymorphisms in barley: mendelian inheritance, chromosomal location, and population dynamics. Proceedings of the National Academy of Sciences of the United States of America 81: 8014-8018.

SAS. 1999. Statistical Analysis Software (SAS 9.1 System for Windows, SAS Institute Inc., Carry, NC, USA).

SigmaPlot. 2000. SigmaPlot (Systat Software, San Jose, CA).

Silveira SF da S et. al. 2013. Desempenho de genótipos de aveia branca em resposta ao estresse por alumínio. Bragantia 72: 319-325.

Silveira SF da S et. al. 2014. Resposta de plântulas de aveia ao estresse por ácidos acético e butírico. Bragantia 73: 345-356.

Sokal R and Michener C. 1958. A statistical method for evaluating systematic relationships. University of Kansas Scientific Bulletin 28: 14091438.

Sokal RR and Rohlf FJ. 1962. The Comparison of Dendrograms by Objective Methods. Taxon 11: 33.

Sultan MARF et. al. 2012. Assessment of Drought Tolerance of Some Triticum L. Species through Physiological Indices. Czech Journal of Genetics and Plant Breeding 48: 178-184.

Taiz L and Zeiger E. 2006. Fisiologia Vegetal. Porto Alegre: Artmed. 